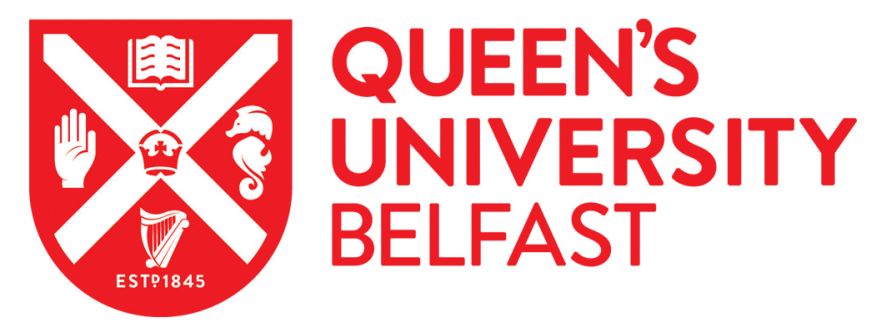

\title{
Queering the Family: Attitudes towards Lesbian and Gay Relationships and Families in Northern Ireland
}

McAlister, S., Carr, N., \& Neill, G. (2014). Queering the Family: Attitudes towards Lesbian and Gay Relationships and Families in Northern Ireland. ARK. http://www.ark.ac.uk/publications/updates/Update89.pdf

\section{Document Version:}

Publisher's PDF, also known as Version of record

Queen's University Belfast - Research Portal:

Link to publication record in Queen's University Belfast Research Portal

\section{General rights}

Copyright for the publications made accessible via the Queen's University Belfast Research Portal is retained by the author(s) and / or other copyright owners and it is a condition of accessing these publications that users recognise and abide by the legal requirements associated with these rights.

Take down policy

The Research Portal is Queen's institutional repository that provides access to Queen's research output. Every effort has been made to ensure that content in the Research Portal does not infringe any person's rights, or applicable UK laws. If you discover content in the Research Portal that you believe breaches copyright or violates any law, please contact openaccess@qub.ac.uk. 


\section{(d) Research Update}

\section{Queering the Family:}

Attitudes towards Lesbian and Gay

\section{Relationships and Families in Northern Ireland}

\section{Siobhán McAlister, Nicola Carr \& Gail Neill}

The Northern Ireland Life and Times (NILT) Survey has asked questions on lesbian, gay, bisexual and transgender (LGBT) issues since 1998. To date survey data have focused primarily on issues relating to prejudice, discrimination and tolerance. In 2012 a range of questions focussing more specifically on $\mathrm{LGBT}^{1}$ issues was included. This collected information on knowledge and perceptions of the LGBT population; personal prejudice; attitudes on equality issues; the visibility of LGBT people and family-related issues.

This update provides an overview of some of the information emerging from this data. It discusses attitudes towards same-sex relations and notable changes over time. Given recent political debate the primary focus of this paper is on attitudes relating to 'queer' marriage, family and parenting. We use the term 'queer' here to refer to 'the diverse family structures formed by those with non-normative gender behaviours or sexual orientations' (Bernstein and Reimann, 2001:3). As previous updates have noted, there have been significant legislative and policy changes in this area Jarman, 2010) and this continues with ongoing discussions regarding the development of a Sexual Orientation Strategy for Northern Ireland (Gray et al, 2013).

\section{Legislative landscape}

Over the last sixteen years there have been a number of pieces of legislation introduced

${ }^{1}$ The majority of questions addressed here (unless otherwise stated) refer to lesbian and gay rather than bisexual and transgender people. within Northern Ireland to address discrimination based on the grounds of sexual orientation. These have sought to -

- $\quad$ ensure that public bodies promote equality of opportunity for persons of different sexual orientations Northern Ireland Act 1998 (Section 75);

- ensure that same-sex parents are entitled to the same adoptive and parental leave as their heterosexual counterparts - The Employment (Northern Ireland) Order 2002;

'make it unlawful to discriminate on the grounds of sexual orientation within employment and vocational training' - The Employment Equality (Sexual Orientation) Regulations (NI) 2003;

- 'increase penalties' for offences motivated by 'hate' or hostility towards a person's sexual orientation - The Criminal Justice (No.2) (Northern Ireland) Order 2004;

- enable same-sex couples to obtain legal recognition of their relationship - Civil Partnership Act 2004;

- prohibit discrimination in the provision of goods, facilities and services on the grounds of sexual orientation - The Equality Act (Sex Orientation) Regulations (NI) 2006.

While matters of employment law and protection for LGBT people seemingly receive little negative political attention, legislation relating to matters of family and partnership law have been regularly

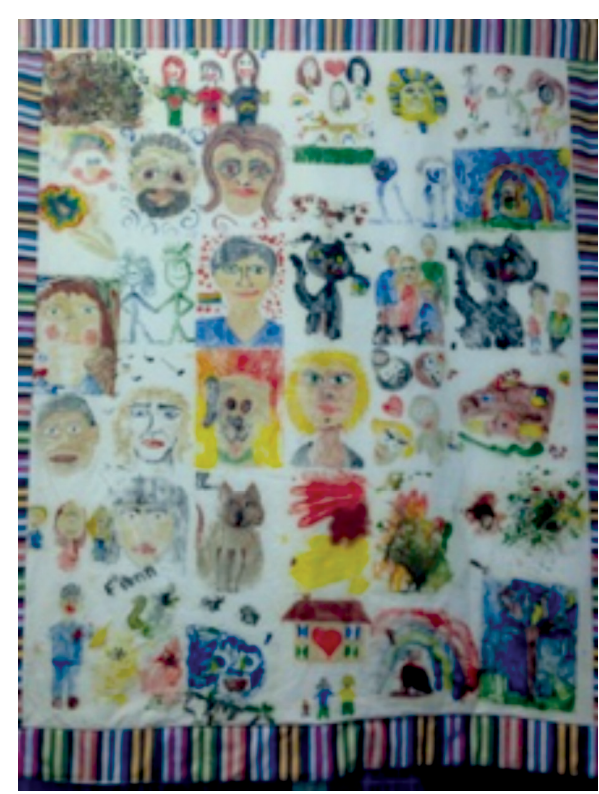

A quilt made by the Family Group of HERe NI

contested. Most recently the debate focused on the Northern Ireland wide ban on gay and unmarried couples applying to adopt children. Northern Ireland was the only jurisdiction where the policy existed and while there were calls to bring it into line with the rest of the UK, this was challenged by the Health Minister. After months of delay a Supreme Court Ruling overturned his appeal.

Within the rest of the UK debates around marriage equality continued in 2013 and resulted in the introduction of the Marriage (Same Sex Couples) Act, which will allow same-sex couples to marry in England and Wales. Similar legislation has recently been passed in Scotland. Within Northern Ireland some political parties have rejected motions calling for the legislation of same-sex marriage and progress remains at a standstill. The moral and religious 
discourse reflected in debates and public commentary on these issues in Northern Ireland has consistently impacted on the speed of policy and legislative change in matters regarding family, parenting, reproduction, sex and sexuality. However, despite the mood of some public debate, there is evidence to suggest positive changes in public attitudes towards lesbian and gay people over time.

\section{Attitudes towards lesbian and gay people}

Social attitude surveys conducted in Northern Ireland over the past two decades show that the numbers of people expressing disapproval of same-sex relations has declined.

The most recent data show continued evidence of improving attitudes towards lesbian and gay people with $73 \%$ of respondents describing themselves as 'not prejudiced at all against gay men' and $76 \%$ reporting similar in respect of lesbians. However, despite indications of more positive changing social attitudes, wider evidence points to continued discrimination towards LGBT people (Gray et al,2013), thus it is instructive to look at the characteristics of those who remain intolerant.

Consistent with previous attitudinal surveys age, gender and religion are associated with positive/negative attitudes towards lesbian and gay people and LGBT issues (Jarman, 2010; Hayes \& Dowds forthcoming). Females and those aged under 65 are more likely to report positive attitudes. Respondents declaring a Protestant affiliation are more likely to report negative attitudes towards lesbian and gay people than Catholics or people declaring 'no religion'.

Research shows that beliefs held about homosexuality influence attitudes. People who view homosexuality as a 'choice' tend to hold more negative views towards gay people and are less likely to support gay rights than those who believe that sexual orientation cannot be changed (Herek, 2000). The NILT Survey (2012) supports this finding and shows that the belief that sexual orientation is a 'choice' is one of the strongest predictors of holding negative views towards lesbian and gay people.

Figure 1: Percentage of respondents who believe that sexual relations between two adults of the same sex is 'always wrong'

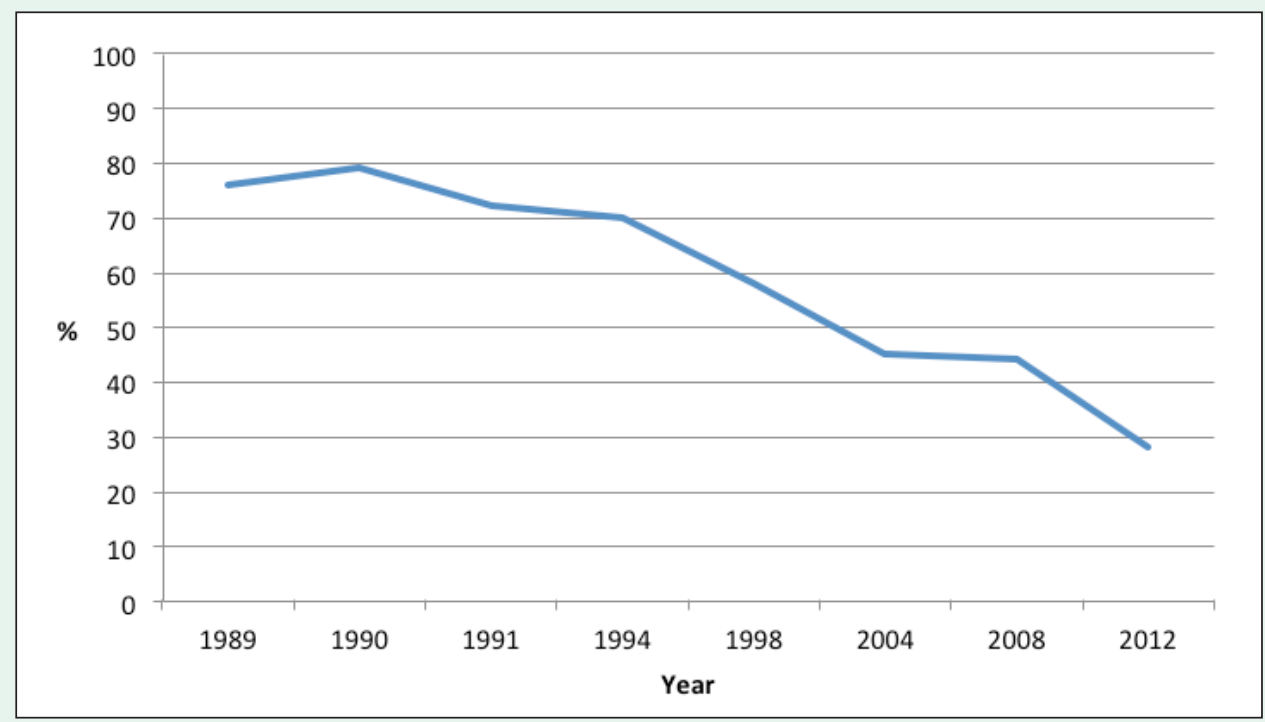

Knowing someone who is gay or lesbian is a predictor of more positive attitudes. In the seven years between 2005 and 2012 there has been a substantial increase in the proportion of people who said that they knew someone who was lesbian or gay. This has risen from $46 \%$ in 2005 to $70 \%$ in 2012.

Given the ameliorating effects of interpersonal contacts (Herek, 2000), the rise in people reporting knowing someone who is lesbian or gay is likely to have positively impacted on attitudes.

\section{Rights to marriage and parenting}

Alongside changes in attitudes towards lesbian and gay people there have also been changes in attitudes towards the rights of same-sex couples. In 2005 for example, only $35 \%$ of respondents agreed that lesbian or gay couples should have the right to marry. Seven years later, the majority of the sample (58\%) felt that marriage between same-sex couples should be legally recognised, granting the same rights as 'traditional marriages'. There is, however, a sizable proportion of the sample who do not favour same-sex marriage. Support for same-sex marriage appears to decrease with age - $74 \%$ of the youngest age group are supportive, whereas this falls to only $30 \%$ amongst the oldest age group. Further, while the majority of those who defined as having no religion (74\%) or as Catholic (66\%), supported same-sex marriage, less than half (45\%) of those defining as Protestant were in support of it. Men were less likely than women to be supportive, as were those who did not know someone who was gay.

While over half of the sample approved of same-sex marriage, once matters of fertility and parenting were introduced, support was less evident (see Table 1). Indeed, over one third actively disapproved of adoption by gay couples and to lesbians having access to IVF on the same terms as heterosexual women.

Bernstein and Reimann (2001: 9) note that it is in the issue of parenting children that heteronormativity (i.e. assumed heterosexuality and gender roles) is at its strongest, and that lesbian and gay parenting unsettles many heteronormative assumptions. This includes common beliefs that children require opposite sex parents and that sexual activity is for the purpose of procreation.

Logistic regression modelling was carried out to look at the range of factors that best predict lack of approval for same-sex marriage,lesbian and gay adoption and access to IVF for lesbians. This reveals some highly consistent patterns (see Table 2). Across all, a person believing that sexual orientation is a 'choice' rather than something that people are born with is the best predictor of disapproval. Other consistent predictors are a Protestant religious affiliation, regular church attendance (attending once or more a week) and being older. 
Finally, with regards to the data on adoption, it is noteworthy that a significant proportion of the sample neither approves nor disapproves of adoption by lesbian or gay couples (around one-quarter). This implies that this group do not have strong feelings either way, and could be influenced towards support. It is also instructive that there appears to be a significant softening of attitudes. In 1989 , for example, only $11 \%$ of people thought that lesbians should be allowed to adopt a baby under the same conditions as heterosexual couples, and only $5 \%$ thought this of gay couples. By 2012 , the figures had risen to $40 \%$ and $36 \%$ respectively. Yet the increased public acceptance is not being mirrored in political decisions.

\section{Attitudes towards 'the family'}

The dominant or 'privileged construct' of the family in Western societies is the heterosexual married couple and their (preferably) biological children. This is normalised and promoted by social institutions (the school, church, media etc.) and legitimised by law and policy. Ironically, despite its privileged position, the numbers of heterosexual married couples with children is declining (NISRA, 2012; ONS, 2012). Yet, this dominant image is reflected in the attitudes of respondents about what they feel constitutes 'a family'. Almost all (98\%) felt that a married heterosexual couple with a child constituted a family. The hierarchy of family types that follows (see Table 3) illustrates further heteronormative and gendered assumptions. While heterosexual marriage is the preferred option, the next best thing - still founded on the assumption

Table 1: Views on equal access to marriage, adoption and IVF

\begin{tabular}{|l|c|c|c|c|}
\hline & $\begin{array}{c}\text { Approve } \\
\text { or support }\end{array}$ & $\begin{array}{c}\text { Neither } \\
\text { approve nor } \\
\text { disapprove }\end{array}$ & $\begin{array}{c}\text { Disapprove } \\
\text { or do not } \\
\text { support }\end{array}$ & Don't know \\
\hline Same-sex marriage & 58 & $\%$ & $\%$ & $\%$ \\
\hline Adoption - lesbian couples & 40 & 25 & 29 & 11 \\
\hline Adoption - gay couples & 36 & 23 & 36 & 5 \\
\hline IVF for lesbian couples & 47 & - & 39 & 15 \\
\hline
\end{tabular}

Table 2:Top three predictors of disapproval/ lack of support for equal access to marriage, adoption and IVF

\begin{tabular}{|c|l|l|l|l|}
\hline \multicolumn{1}{|c|}{$\begin{array}{c}\text { Same-sex } \\
\text { marriage }\end{array}$} & \multicolumn{1}{|c|}{$\begin{array}{c}\text { Adoption - } \\
\text { Lesbian couples }\end{array}$} & \multicolumn{1}{|c|}{$\begin{array}{c}\text { Adoption }- \\
\text { Gay couples }\end{array}$} & \multicolumn{1}{|c|}{$\begin{array}{c}\text { IVF for } \\
\text { Lesbian couples }\end{array}$} \\
\hline I & $\begin{array}{l}\text { Sexual orientation } \\
\text { a choice }\end{array}$ & $\begin{array}{l}\text { Sexual orientation } \\
\text { a choice }\end{array}$ & $\begin{array}{l}\text { Sexual orientation } \\
\text { a choice }\end{array}$ & $\begin{array}{l}\text { Sexual orientation } \\
\text { a choice }\end{array}$ \\
\hline 2 & Older & $\begin{array}{l}\text { Protestant } \\
\text { affiliation }\end{array}$ & Older & $\begin{array}{l}\text { Protestant } \\
\text { affiliation }\end{array}$ \\
\hline 3 & $\begin{array}{l}\text { Protestant } \\
\text { affiliation }\end{array}$ & $\begin{array}{l}\text { Regular church } \\
\text { attendance }\end{array}$ & $\begin{array}{l}\text { Protestant } \\
\text { affiliation }\end{array}$ & $\begin{array}{l}\text { Regular church } \\
\text { attendance }\end{array}$ \\
\hline
\end{tabular}

that the child has the benefit of both a female and male influence and role model - is for both heterosexual parents to be present, even if not married. Less popular, but preferable to non-heterosexual parents is the heterosexual lone mother, closely followed by the heterosexual lone father. While there was less support for heterosexual lone parents, the majority of respondents still viewed them as 'a family'. On the other hand, no matter what form they took, at least one in four, and as many as one in three respondents felt that a lesbian or gay parent(s) with a child (i.e. a queer family) did not constitute 'a family'. This may be because in 'constructing families that challenge the heterosexual norm' (Wilson,
2007: 56), lesbian and gay families disrupt common assumptions about both gender and sexuality. Thus, while two parents are preferred in heterosexual families, this is not the case for lesbian or gay families.

\section{Conclusion}

Throughout the analysis consistent findings emerged. With regards to views on marriage, family and parenting the best predictor of attitudes was whether or not the respondent believed sexual orientation was a 'choice'. Being Protestant, being older, attending church regularly and not knowing someone who is lesbian or gay were also good predictors of less approving/ supportive attitudes.

Table 3: Identification of what constitutes 'a family'

\begin{tabular}{|l|c|c|c|c|}
\hline & \multicolumn{3}{|c|}{$\%$} \\
\cline { 2 - 5 } & $\begin{array}{c}\text { Yes, } \\
\text { definitely }\end{array}$ & $\begin{array}{c}\text { Yes, } \\
\text { probably }\end{array}$ & $\begin{array}{c}\text { No, } \\
\text { probably not }\end{array}$ & $\begin{array}{c}\text { Non't know } \\
\text { definitely not }\end{array}$ \\
\hline A married heterosexual couple with a child & 80 & 18 & $<1$ & 1 \\
\hline An unmarried heterosexual couple with a child & 62 & 32 & 3 & 2 \\
\hline A heterosexual lone mother with a child & 55 & 34 & 6 & 3 \\
\hline A heterosexual lone father with a child & 55 & 33 & 6 & 4 \\
\hline A lesbian lone mother with a child & 37 & 33 & 13 & 12 \\
\hline A lesbian couple with a child & 33 & 32 & 13 & 17 \\
\hline A gay lone father with a child & 35 & 29 & 16 & 15 \\
\hline A gay couple with a child & 33 & 30 & 14 & 18 \\
\hline
\end{tabular}


In broad terms there have been positive changes in attitudes towards lesbian and gay people in Northern Ireland over the past two decades. Attitudes towards samesex relations have softened and there is an acceptance of a wider construction of 'the family'. That said, a hierarchy remains whereby heterosexual marriage, families and parenting is privileged above all else. Attitudinal change coinciding with increased attention to gay and lesbian people and issues of gay rights has occurred in other countries (Anderson \& Fetner, 2008; Baunach, 2012). Whether policy and legislative change is cause or effect is debated, it is nevertheless important in respect of public attitudes.

\section{References}

Anderson, R. \& Fetner,T. (2008) 'Cohort differences in tolerance of homosexuality. Attitudinal change in Canada and the United States.' Public Opinion Quarterly, 72,2: 311-330.
Baunach, D. M. (2012) 'Changing Same-Sex Marriage Attitudes in American from 1988 through 2010.' Public Opinion Quarterly, 76,2: 364-378.

Bernstein, M. and Reimann, R. (2001) 'Queer families and the politics of visibility' in Bernstein, M. and Reimann, R. (eds.) Queer Families, Queer Politics: Challenging Culture and the State, New York: Columbia University Press, pp.1- 19.

Gray,A., Horgan, G. \& Leighton,A. (2013)

'Moving towards a Sexual Orientation Strategy for Northern Ireland.' Ark Policy Brief. http://www.ark.ac.uk/pdfs/ policybriefs/pbso.pdf.

Hayes, B.C. \& Dowds, L. (2014 forthcoming) 'Religion and attitudes towards gay rights in Northern Ireland : the God gap revisited.' In Stanley D. Brunn (ed.), The Changing World Religious Map: Sacred Places, Identities, Practices and Politics. New York: Springer.
Herek, G. M. (2000) 'The psychology of Sexual Prejudice.' Current Directions in Psychological Science, 9: 19-22.

Jarman, N. (2010) 'Attitudes towards Lesbian, Gay and Bisexual people in Northern Ireland.' Research Update, 66, March 2010. Belfast:ARK. http://www.ark. ac.uk/publications/updates/update66.pdf.

NISRA (2012) Census 2011: Key Statistics for Northern Ireland, Belfast: NISRA.

ONS (2012) Statistical Bulletin: Family and Households 2012, London: ONS.

Wilson, A. R. (2007) 'With friends like these:The liberalization of queer family policy', Critical Social Policy, 27 (1): 50-76.

\section{Key points}

- The proportion of people who believe that same-sex relations are 'always wrong' has dropped from $76 \%$ in 1989 to $28 \%$ in 2012 .

- $73 \%$ of people describe themselves as 'not prejudiced at all against gay men' and $76 \%$ report the same in respect of lesbians.

- People who view homosexuality as a 'choice' tend to hold negative views towards gay people and are less likely to support gay rights than those who believe that sexual orientation cannot be changed.

- Other predictors of negative views include a Protestant religious affiliation, being older and regular church attendance.

- Knowing someone who is gay or lesbian is a predictor of more positive attitudes.

- In 2005 only $35 \%$ of people felt that lesbian or gay couples should have the right to marry. By 2012 the majority (58\%) felt that marriage between same-sex couples should be legally recognised.

- At least one in four and as many as one in three people felt that a lesbian or gay parent(s) with a child did not constitute 'a family'.

Siobhán McAlister is a Lecturer in the School of Sociology, Social Policy and Social Work, Queen's University, Belfast. Nicola Carr is a Lecturer in the School of Sociology, Social Policy and Social Work, Queen's University Belfast. Gail Neill is a youth worker and freelance trainer working in the areas of gender and sexuality.

The questions on LGBT were funded by the Office of the First Minister and Deputy First Minister (OFMDFM) and we are grateful to them for their support.

The Northern Ireland Life and Times survey (NILT) is carried out annually and documents public opinion on a wide range of social issues. NILT is a joint project of the two Northern Ireland universities and aims to provide an independent source of information on what the public thinks about the social issues of the day. Check the web site for more information on the survey findings (www.ark.ac.uk/nilt) or call the survey director on 02890973034 with any queries.

\section{In collaboration with Queen's University Belfast and University of Ulster}

Magee campus, University of Ulster

Northland Road, Londonderry BT48 7JA

Tel: 02871675513 Fax: 02871675510

E-mail: info@ark.ac.uk
School of Sociology, Social Policy and Social Work

Queen's University Belfast BT7 1NN

Tel: 02890973034 Fax: 02890973943

E-mail: info@ark.ac.uk 